\title{
Covid-19 Pandemic Experiences Of Filipinos: Basis For The Development Of A Coping Program
}

\author{
Venus A. Vitales ${ }^{1}$, Clarinda A. Reyes ${ }^{2}$, Karen Jann M. Aquino ${ }^{3}$, Reymond P. Senia ${ }^{4}$ \\ 1,2,3,4Social and Behavioral Sciences Department, College of Arts and Sciences, Nueva Ecija University of Science and \\ Technology, Cabanatuan City, Philippines \\ ${ }^{1}$ ven_vi@yahoo.com, ${ }^{2}$ clarinda3afable@gmail.com, ${ }^{3}$ karenjannmacasoaquino@gmail.com, ${ }^{4}$ raymondsenia@yahoo.com
}

\begin{abstract}
The Luzon lockdown due to the Covid-19 pandemic brought varying reactions, emotions and actions to mankind. Fear, uncertainty, and anxiety were experienced by everyone. Only the frontliners were allowed to go out, while everybody was advised to stay home. This research explored and compared the coping strategies of Filipinos across gender and generations to come up with a coping program to overcome the effects of the pandemic. One-hundred males and one-hundred females with 50 individuals from each generation participated in the survey and were interviewed online during the lockdown. Analysis of their response showed that their coping strategies were composed of five-psychologicalspiritual coping strategies; three-economic-political coping strategies; and three-social coping strategies. The psychological-spiritual coping strategy of "praying and keeping in mind to ask God to end Covid-19 pandemic so that people will not suffer" was the foremost coping strategy of both male and female Baby Boomers, Generation Y as well as female Generation X and Generation Z respondents; but it vary among the male Gen X and Gen Z. Significant difference was established between one item of the psychological-spiritual coping strategies and generation category; while no significant difference was established between the coping strategies and gender of the respondents, an indication that male and female equally needs the proposed coping program "Tara, Usap Tayo, CASama Mo Ako-SBS Psych Aid", where various programs are continuously implemented in collaboration with other offices of the university, for the stakeholders from various sectors, university-wide and nationwide.
\end{abstract}

Keywords

Covid-19, Coping Strategies, Gender, Baby Boomers, Gen X, Gen Y, Gen Z, Lockdown

Article Received: 10 August 2020, Revised: 25 October 2020, Accepted: 18 November 2020

\section{Introduction}

In the Philippines, Luzon was placed under lockdown due to the Covid-19 pandemic starting March 17, 2020 until last week of May 2020. The pandemic brought varying reactions and actions to the Filipinos. Feelings of fear, uncertainty, and anxiety; and acts such as panic-buying, alcohol and sanitizer hoarding and committing of crimes became prevalent among the individuals during the lock down. Students and employees were refrained from going to school and work. Only those who are working as frontliners were allowed to go out. Various checkpoints, manned by men in uniforms and health-workers, are seen everywhere. Some students and workers are stranded in their boarding houses and dormitories. In short, nothing seems normal anymore. These drastic change brought about by the Covid-19 pandemic were experienced all over the world and it affected everyone physically, financially, mentally, emotionally and even environmentally. Thus, it became a growing concern among counselors and other mental health professionals to come up with solutions to ease the effects of the Covid-19 pandemic.

An individual who experienced fear, anxiety, stress and other negative emotions and behaviors may react positively or negatively. The tendency for the individual to cope with the situation is a normal reaction. Lazarus and Folkman (1984), one of the pioneers of coping theories, defined it as "constantly changing cognitive and behavioral efforts used to manage specific external and internal demands which are taxing or exceeding the resources of the person". This definition entails five (5) factors. First, coping involves spending mental energy in a way that can reduce stress. Second, whether conscious or subconscious, coping mechanisms' goal is to solve problems and return to homeostasis. Third, coping strategies can be positive or negative, depending on whether they increase or reduce mental wellbeing. Fourth, coping is dependent on personality patterns and perceptual experiences; and fifth, the strategies one chose to adapt to a situation is highly individualized. Coping is never the same for two people, although everybody needs to cope with a certain situation that an individual experienced such as the Covid-19 pandemic.

Every individual possess varying characteristics, whether it is from the perspective of gender or generation. In an article written by Jerabek (2017), he compared the coping styles of individuals from various generational groups. It was revealed that younger people are more likely to resort to distraction to cope with difficulties in their life. Furthermore, they stated that both Baby Boomers and Generation X individuals use healthy strategies. Their top 5 stress management tactics includes Problem-Solving, Positive Cognitive Restructuring, Negotiation, Informationseeking, and Emotional Regulation.

The strength and weakness of each generation was described in the website of getsmarter.com. The strengths of Baby Boomers include being workaholics; committed to their roles; good team players; and excellent mentors; while their weaknesses were their preference for structure and discipline, their less inclination to welcome change; their being competitive and their need for recognition and rewards to keep them motivated; and they are the least tech 
savvy of all generations. The strengths of the Generation X were being the best overall workers; committed to juggling work with family time; they favor work-life balance in an organization; and they are considered to be the biggest revenue generators; while their weaknesses include their less inclined to say something if they disagreed on something; and they value being able to do things quickly. The strengths of Generation Y were being the most independent; concerned with ethics and the social responsibility; they have grown up sourcing information; and create their own processes rather than being told what to do; while their weaknesses include being not interested in teamwork; they do not have strong work ethic; and impatient. The Generation Z's strengths were being tech competent; able to pick up new developments quickly; ambitious; natural entrepreneurs; and can multitask using up to five screens at once; while their weaknesses are being cynical; more realistic outlook over the idealism; and they are very reliant on technology to solve problems.

In terms of gender, Endler and Parker (1994) have found that women tend to use coping strategies that are aimed at changing their emotional responses to a stressful situation, whereas men use more problem-focused or they utilized instrumental methods of handling stressful experiences.

Guided by the above information on the characteristics of the four generations and the experience of the Filipinos during the lockdown, the researchers examined the respondents' coping mechanisms to come up with a coping program that could be useful for the individuals who experienced the effects of the Corona Virus -19 (COVID19) pandemic.

\section{Objectives}

1. To describe the coping strategies of the respondents across generation and gender

2. To establish the significant differences in the coping strategies of the respondents across generation and gender.

3. To come up with a Covid-19 pandemic coping program that is useful for the individuals across generation and gender.

4.

\section{Hypothesis}

There is no significant difference in the coping strategies of the respondents across generation and gender.

\section{Methods}

This research was a qualitative study that examined the coping strategies of individuals from four generations and according to their gender. The Covid-19 experience was new to the respondents, thus their response in terms of coping was also new. The coping mechanism theory of Lazarus and Folkman (1984) was used as guide by the researcher. Data gathering was conducted through the use of online survey using Google forms, supported by interviews through messengers and text messaging. Included in the Google form survey was the informed consent and information about data privacy law of which the respondents agreed upon answering the questionnaire. The researcher forwarded the survey questionnaire to individuals through their social media friend's list, and asked them to forward the survey questionnaire to other individuals. Snowballing technique was employed until the total number of respondents was reached, which was 50 respondents $(25$ male and 25 female) from each generation (Baby Boomer, Gen X, Gen Y and Gen Z). The survey questionnaire contained instructions for the respondents to enumerate the activities that they did to cope during the lockdown due to the Covid-19 pandemic from March 17 to May 25, 2020. Analysis of data was done using frequency, rank and Analysis of Variance test.

\section{Results And Discussions}

\section{Profile Characteristics of the Respondents in terms of Generation Category and Gender}

Table 1. Distribution of the Respondents According to their Gender and Generation

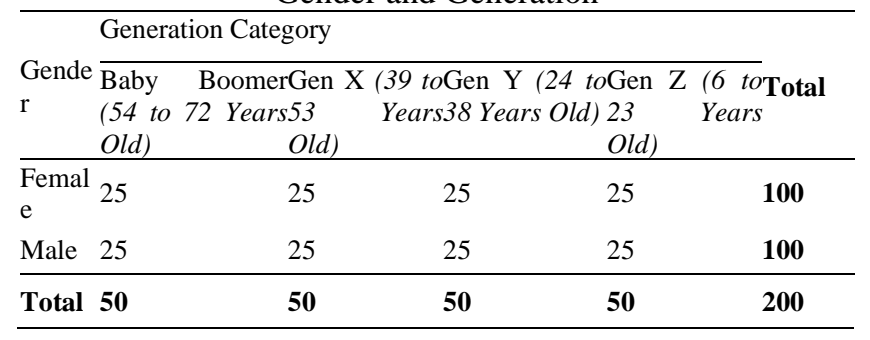

The number of respondents by gender and generation was equally divided. From the total of 200 respondents; 100 were male and 100 were female; and 50 respondents from each generation of baby boomers, generation $\mathrm{x}$, generation $\mathrm{y}$ and generation $\mathrm{z}$, which is divided into 25 males and 25 females. This sampling technique was used hence the variables gender and generation was used as basis for comparison of their Covid-19 pandemic experiences and coping strategies. Convenience sampling was used in obtaining the number of respondents from each generation and gender. The categorization used to identify the respondents from the four generations was taken from careerplanner.com. Baby Boomers were those who were 54 to 72 years old; Generation $\mathrm{X}$ were those whose age was 39 to 53 years old; Generation $\mathrm{Y}$ also known as Millennials or Next Gen were those whose age was 24 to 38 years old; and Generation $\mathrm{Z}$ also known as iGen were those who were 6 to 23 years old. In this research, the age of Gen $\mathrm{Z}$ was limited to 18 to 23 years old, hence, parental consent will be required if the respondent is below 18 .

\subsection{Coping Strategies of the Respondents}

Table 2.1 Categories of the Identified Coping Strategies of the Respondents

\begin{tabular}{|c|c|c|}
\hline Coping Strategy & $\begin{array}{l}\text { Number of } \\
\text { Identified } \\
\text { Strategy }\end{array}$ & Rank \\
\hline $\begin{array}{ll}\text { Psychological-Spiritual } & \text { Coping } \\
\text { Strategies } & \end{array}$ & 5 & 1 \\
\hline Economic-Political Coping Strategies & 3 & 2 \\
\hline Social Coping Strategies & 3 & 3 \\
\hline Total & 11 & \\
\hline
\end{tabular}


The qualitative analysis of the respondents' coping strategies revealed that they used eleven (11) coping strategies during the Covid-19 pandemic lockdown. The coping strategies were: five (5) psychological-spiritual; three (3) economic-political; and three (3) social coping strategies. The specific statements of the coping strategies in the identified three factors was presented and described in Table 2.2.

Table 2.2 Items of the Coping Strategies of the Respondents according to their Generation and Gender

\begin{tabular}{|c|c|c|c|c|c|c|c|c|}
\hline \multirow[t]{2}{*}{ Coping Strategies } & \multicolumn{2}{|c|}{$\begin{array}{l}\text { Baby } \\
\text { Boo } \\
\text { mers } \\
\end{array}$} & \multicolumn{2}{|c|}{$\begin{array}{l}\text { Gener } \\
\text { ation } \\
\mathbf{X}\end{array}$} & \multicolumn{2}{|c|}{$\begin{array}{l}\text { Gener } \\
\text { ation } \\
\text { Y }\end{array}$} & \multicolumn{2}{|c|}{$\begin{array}{l}\text { Gener } \\
\text { ation } \\
Z\end{array}$} \\
\hline & $\mathbf{F}$ & $\mathbf{M}$ & $\mathbf{F}$ & $\mathbf{M}$ & $\mathbf{F}$ & M & $\mathbf{F}$ & M \\
\hline $\begin{array}{l}\text { Psychological-Spiritual } \\
\text { Strategies }\end{array}$ & $\mathbf{n}$ & $\mathbf{n}$ & $\mathbf{n}$ & $\mathbf{n}$ & $\mathbf{n}$ & $\mathbf{n}$ & $\mathbf{n}$ & $\mathbf{n}$ \\
\hline 1. I prayed and always keep & 2 & 2 & 2 & 1 & 2 & 22 & 2 & 18 \\
\hline $\begin{array}{l}\text { in mind to ask God to end the Covid- } \\
19 \text { pandemic so that we will not } \\
\text { suffer. }\end{array}$ & 4 & 4 & 3 & 9 & 4 & & 2 & \\
\hline 2. I become sad and anxious & 2 & 2 & 1 & 1 & 2 & 19 & 2 & 13 \\
\hline $\begin{array}{l}\text { about news on the death toll because } \\
\text { of Covid- } 19 \text { pandemic; so I offered } \\
\text { prayers for them. }\end{array}$ & 3 & 1 & 9 & 8 & 2 & & 1 & \\
\hline 3. I amused myself in order & 2 & 2 & 1 & 1 & 1 & 21 & 2 & 20 \\
\hline $\begin{array}{l}\text { not to get depressed; my daily routine } \\
\text { was eat, sleep, watch TV, surf the } \\
\text { internet/play online games. }\end{array}$ & 3 & 1 & 6 & 7 & 9 & & 0 & \\
\hline 4. I kept myself busy, by & 1 & 1 & 1 & 1 & 1 & 15 & 1 & 10 \\
\hline $\begin{array}{l}\text { cleaning the house and my backyard } \\
\text { so that I won't think of Covid- } 19 \text {. }\end{array}$ & 7 & 9 & 8 & 6 & 8 & & 5 & \\
\hline 5. I stayed at home and I got & 1 & 1 & 1 & 2 & 1 & 18 & 1 & 16 \\
\hline $\begin{array}{l}\text { bored; I asked God why Covid-19 } \\
\text { pandemic happened. }\end{array}$ & 5 & 6 & 0 & 1 & 4 & & 9 & \\
\hline Total & $\begin{array}{l}\mathbf{8} \\
2\end{array}$ & $\begin{array}{l}\mathbf{8} \\
\mathbf{1}\end{array}$ & $\begin{array}{l}6 \\
9\end{array}$ & $\begin{array}{l}7 \\
3\end{array}$ & $\begin{array}{l}7 \\
8\end{array}$ & 76 & $\begin{array}{l}7 \\
8\end{array}$ & 62 \\
\hline $\begin{array}{ll}\text { Economic-Political } & \text { Coping } \\
\text { Strategies } & \\
\end{array}$ & & & & & & & & \\
\hline $\begin{array}{l}\text { 1. I made my vacation } \\
\text { productive by cultivating vegetables } \\
\text { in my backyard/ I grow different } \\
\text { plants and earned some money by } \\
\text { selling them. }\end{array}$ & $\begin{array}{l}1 \\
7\end{array}$ & $\begin{array}{l}1 \\
9\end{array}$ & $\begin{array}{l}1 \\
8\end{array}$ & $\begin{array}{l}1 \\
6\end{array}$ & $\begin{array}{l}1 \\
8\end{array}$ & 15 & $\begin{array}{l}1 \\
5\end{array}$ & 10 \\
\hline $\begin{array}{l}2 . \quad \text { I released my anger by } \\
\text { ranting about politicians who are not } \\
\text { helping their constituents; and I got } \\
\text { pissed off with news about the } \\
\text { corruptions of local government } \\
\text { officials everywhere. }\end{array}$ & 9 & 9 & 9 & 7 & $\begin{array}{l}1 \\
4\end{array}$ & 9 & $\begin{array}{l}1 \\
1\end{array}$ & 9 \\
\hline $\begin{array}{l}\text { I. joined people who went } \\
\text { panic buying on alcohol, sanitizers, } \\
\text { and groceries that's why supplies and } \\
\text { stocks in groceries and supermarkets } \\
\text { run out. }\end{array}$ & 7 & $\begin{array}{l}1 \\
0\end{array}$ & 9 & $\begin{array}{l}1 \\
0\end{array}$ & $\begin{array}{l}1 \\
1\end{array}$ & 8 & 7 & 7 \\
\hline Total & $\begin{array}{l}4 \\
4\end{array}$ & $\begin{array}{l}\mathbf{5} \\
\mathbf{1}\end{array}$ & $\begin{array}{l}4 \\
8\end{array}$ & $\begin{array}{l}4 \\
4\end{array}$ & $\begin{array}{l}5 \\
7\end{array}$ & 43 & $\begin{array}{l}4 \\
4\end{array}$ & 35 \\
\hline Social Coping Strategies & & & & & & & & \\
\hline $\begin{array}{l}\text { I bonded with my family at } \\
\text { home while we all stayed at home } \\
\text { together. }\end{array}$ & $\begin{array}{l}2 \\
0\end{array}$ & $\begin{array}{l}2 \\
0\end{array}$ & $\begin{array}{l}2 \\
2\end{array}$ & $\begin{array}{l}1 \\
5\end{array}$ & $\begin{array}{l}1 \\
7\end{array}$ & 15 & $\begin{array}{l}1 \\
9\end{array}$ & 14 \\
\hline $\begin{array}{l}2 . \quad \text { I posted my rants and } \\
\text { frustrations on social media about } \\
\text { what I heard around me. }\end{array}$ & 5 & $\begin{array}{l}1 \\
0\end{array}$ & 5 & 5 & 6 & 6 & 9 & 6 \\
\hline $\begin{array}{l}3 . \quad \text { I get in-touch with } \\
\text { friends/family members who got } \\
\text { stranded somewhere else and were not } \\
\text { able to go home to their families. }\end{array}$ & 5 & 6 & 5 & 7 & 8 & 9 & 6 & 5 \\
\hline Total & $\begin{array}{l}4 \\
\mathbf{0}\end{array}$ & $\begin{array}{l}4 \\
8\end{array}$ & $\begin{array}{l}4 \\
3\end{array}$ & $\begin{array}{l}3 \\
6\end{array}$ & $\begin{array}{l}4 \\
1\end{array}$ & 40 & $\begin{array}{l}4 \\
5\end{array}$ & 33 \\
\hline
\end{tabular}

The coping strategies of the respondents during the lockdown due to Covid-19 pandemic were categorized as psychological-spiritual coping strategies, economic-political coping strategies and social coping strategies. The respondents provided multiple responses. Of the eleven coping strategies, their topmost coping strategy was psychological-spiritual, specifically the item which states that "they prayed and always kept in their mind to ask God to end the Covid-19 pandemic, so that people will not suffer". This item was the rank 1 answers of both male and female Baby Boomers and Generation Y; and female Generation X and Generation Z. Only male Generation X and Generation $\mathrm{Z}$ did not consider this as their first coping strategy during the pandemic. The Philippines is known as a Christian country which means most Filipinos are devoted in their religious beliefs including their faith in God.

The male Generation $\mathrm{X}$ respondents' topmost coping strategy was "Confined themselves at home and felt very bored; and asked God why Covid-19 pandemic happened"; while male Generation Z's topmost coping strategy was "Amused themselves in order not to get depressed because of the pandemic; their daily routine was stayed at home, eat, sleep, watched TV and surf the internet/play online games". According to Jerabek (2017) younger people are more likely to resort to distraction to cope with difficulties in their life, thus male members of Generation $\mathrm{Z}$ preferred to cope by watching television and surfing the net or playing online games to distract them from worrying. Relying too much on technology to solve problems was considered as weakness of the Gen $\mathrm{Z}$ as mentioned in the review of studies.

On the other hand, the last in the list of the coping strategies of the respondents was the social coping strategy of "Getting in touch with their family who got stranded in another place and away from them". This was their least coping strategy because most of the respondents' families were together before the lockdown was enforced in their respective municipalities and cities.

\section{Comparison of the Significant Differences in the Coping Strategies of the Respondents across Generation and Gender}

\subsection{Significant Difference in the Coping Strategies and Generation}

Table 3.1.1 ANOVA for the Significant Difference in the Coping Strategies and Generation

\begin{tabular}{|c|c|c|c|}
\hline $\begin{array}{l}\text { Coping Strategies } \\
* \text { Generation }\end{array}$ & $\mathbf{F}$ & Sig. & Interpretation \\
\hline Psychological- & & & Not \\
\hline $\begin{array}{l}\text { Spiritual Coping } \\
\text { Strategies }\end{array}$ & 1.702 & .303 & Significant \\
\hline $\begin{array}{l}\text { Economic-Political } \\
\text { Coping Strategies }\end{array}$ & .908 & .512 & $\begin{array}{l}\text { Not } \\
\text { Significant }\end{array}$ \\
\hline $\begin{array}{ll}\text { Social } & \text { Coping } \\
\text { Strategies } & \end{array}$ & .305 & .821 & $\begin{array}{l}\text { Not } \\
\text { Significant }\end{array}$ \\
\hline
\end{tabular}

The computed F-values for the three coping strategies, namely psychological-spiritual $(\mathrm{F}=1.702)$; economicpolitical $(\mathrm{F}=.908)$; and social $(\mathrm{F}=.305)$ were not significant at .05 level. Although, examining the results of the specific statements of the three coping strategies as presented in 
Table 3.1.2, a significant difference was established between the generation category of the respondents and the psychological-spiritual coping strategy of "Amusing themselves in order not to get depressed because of the pandemic; their daily routine was stayed at home, eat, sleep, watched TV and surf the internet/paly online games" $(F=9.296)$. The same item was the topmost coping strategy of male Generation $\mathrm{Z}$ respondents, while the rest did not consider it as their first coping strategy. This result further explained the characteristics of male Generation $\mathrm{Z}$ individuals, where it was believed that one of the strength of Generation $\mathrm{Z}$ individuals was their being technology competent; they are very much attached to various technologies such as televisions, computers and the internet.

Table 3.1.2 ANOVA for the Significant Difference in the Items of the Coping Strategies and Generation Category

\begin{tabular}{|c|c|c|c|}
\hline Coping Strategies *Generation & $\mathbf{F}$ & $\begin{array}{l}\mathrm{Si} \\
\text { g. }\end{array}$ & $\begin{array}{l}\text { Interpr } \\
\text { etation }\end{array}$ \\
\hline \multicolumn{4}{|l|}{ Psychological-Spiritual Coping Strategies } \\
\hline $\begin{array}{l}\text { 1. I prayed and always keep in mind to } \\
\text { ask God to end the Covid-19 pandemic so that } \\
\text { we will not suffer. } \\
2 . \quad \text { I become sad and anxious about news } \\
\text { on the death toll because of Covid-19 } \\
\text { pandemic; so I offered prayers for them. } \\
3 \text {. I amused myself in order not to get } \\
\text { depressed; my daily routine was eat, sleep, } \\
\text { watch TV, surf the internet/play online games. } \\
4 \text { I kept myself busy, by cleaning the } \\
\text { house and my backyard so that I won't think of } \\
\text { Covid-19. } \\
5 \text { I stayed at home and I got bored; I } \\
\text { asked God why Covid-19 pandemic happened. }\end{array}$ & $\begin{array}{l}9 . \\
29 \\
6 \\
2 . \\
22 \\
2 \\
.0 \\
98\end{array}$ & $\begin{array}{l}.3 \\
4 \\
7 \\
.4 \\
8 \\
2 \\
.0 \\
2 \\
8 \\
.2 \\
2 \\
8 \\
.9 \\
5 \\
7\end{array}$ & $\begin{array}{l}\text { Not } \\
\text { Signific } \\
\text { ant } \\
\text { Not } \\
\text { Signific } \\
\text { ant } \\
\text { Signific } \\
\text { ant }\end{array}$ \\
\hline \multicolumn{4}{|l|}{ Economic-Political Coping Strategies } \\
\hline $\begin{array}{l}1 . \quad \text { I made my vacation productive by } \\
\text { cultivating vegetables in my backyard/ I grow } \\
\text { different plants and earned some money by } \\
\text { selling them. }\end{array}$ & $\begin{array}{l}2 . \\
22 \\
2\end{array}$ & $\begin{array}{l}.2 \\
2 \\
8\end{array}$ & $\begin{array}{l}\text { Not } \\
\text { Signific } \\
\text { ant }\end{array}$ \\
\hline $\begin{array}{l}2 . \\
\text { politicians who are not helping their } \\
\text { constituents; and I got pissed off with news } \\
\text { about the corruptions of local government } \\
\text { officials everywhere. }\end{array}$ & $\begin{array}{l}1 . \\
08 \\
1\end{array}$ & $\begin{array}{l}4 \\
5 \\
2\end{array}$ & $\begin{array}{l}\text { Not } \\
\text { Signific } \\
\text { ant }\end{array}$ \\
\hline $\begin{array}{l}\text { 3. I joined people who went panic } \\
\text { buying on alcohol, sanitizers, and groceries } \\
\text { that's why supplies and stocks in groceries and } \\
\text { supermarkets run out. }\end{array}$ & $\begin{array}{l}1 . \\
17 \\
5\end{array}$ & $\begin{array}{l}.4 \\
2 \\
4\end{array}$ & $\begin{array}{l}\text { Not } \\
\text { Signific } \\
\text { ant }\end{array}$ \\
\hline \multicolumn{4}{|l|}{ Social Coping Strategies } \\
\hline $\begin{array}{l}1 . \quad \text { I bonded with my family at home } \\
\text { while we all stayed at home together. }\end{array}$ & $\begin{array}{l}.7 \\
01\end{array}$ & $\begin{array}{l}.5 \\
9 \\
9\end{array}$ & $\begin{array}{l}\text { Not } \\
\text { Signific } \\
\text { ant }\end{array}$ \\
\hline $\begin{array}{l}2 . \quad \text { I posted my rants and frustrations on } \\
\text { social media about what I heard around me. }\end{array}$ & $\begin{array}{l}.7 \\
06\end{array}$ & $\begin{array}{l}.5 \\
9 \\
7\end{array}$ & $\begin{array}{l}\text { Not } \\
\text { Signific } \\
\text { ant }\end{array}$ \\
\hline $\begin{array}{l}3 . \quad \text { I get in-touch with friends/family } \\
\text { members who got stranded somewhere else and } \\
\text { were not able to go home to their families. }\end{array}$ & $\begin{array}{l}4 . \\
71 \\
4\end{array}$ & $\begin{array}{l}.0 \\
8 \\
4\end{array}$ & $\begin{array}{l}\text { Not } \\
\text { Signific } \\
\text { ant }\end{array}$ \\
\hline
\end{tabular}

The analysis of variance to test the significant difference in the coping strategies of the respondents according to their generation revealed that significant difference was established for one item of the psychological-spiritual coping strategies $(\mathrm{F}=9.296)$ of the respondents and their generation category, the hypothesis of no significant difference for this coping strategy was rejected. The male Generation $\mathrm{Z}$ respondents preferred to cope from the effects of the pandemic during the lockdown by keeping themselves amused so that they will not feel depressed because of the pandemic; they stayed at home, eat, sleep, watched TV and surfing through the internet became their routine; while most of the respondents from the Baby Boomers, Generation $\mathrm{X}$, and Generation $\mathrm{Y}$ preferred to cope by praying and keeping in mind to ask God to end the Covid-19.

Table 3.2.1 ANOVA for the Significant Difference between Coping Strategies and Gender

\begin{tabular}{|c|c|c|c|}
\hline $\begin{array}{l}\text { Coping } \\
\text { Strategies } \\
* \text { Gender } \\
\end{array}$ & $\mathbf{F}$ & Sig. & Interpretation \\
\hline $\begin{array}{l}\text { Psychological } \\
\text { Coping } \\
\text { Strategies }\end{array}$ & .541 & .490 & Not Significant \\
\hline $\begin{array}{l}\text { Economic- } \\
\text { Political } \\
\text { Coping } \\
\text { Strategies }\end{array}$ & 1.376 & .285 & Not Significant \\
\hline $\begin{array}{l}\text { Social Coping } \\
\text { Strategies }\end{array}$ & .781 & .411 & Not Significant \\
\hline
\end{tabular}

No significant difference was established between the male and female respondents' psychological-spiritual coping strategies $(\mathrm{F}=.541)$; economic-political coping strategies $(\mathrm{F}=1.376)$; and social coping strategies $(\mathrm{F}=.781)$. The hypothesis of no significant difference was accepted. This finding was supported by the result in Table 3.2.2, which shows that no specific item-statements in the three coping strategies of the respondents differed in terms of the respondents' gender.

Table 3.2.2 ANOVA for the Significant Difference in the Items of the Coping Strategies and Gender

\begin{tabular}{|c|c|c|c|}
\hline $\begin{array}{ll}\text { Coping } & \text { Strategies } \\
* \text { Gender } & \end{array}$ & $\mathbf{F}$ & Sig. & Interpretation \\
\hline $\begin{array}{l}\text { Psychological Coping } \\
\text { Strategies }\end{array}$ & & & \\
\hline $\begin{array}{l}1 . \quad \text { I prayed and } \\
\text { always keep in mind to } \\
\text { ask God to end the }\end{array}$ & 2.941 & .137 & $\begin{array}{l}\text { Not } \\
\text { Significant }\end{array}$ \\
\hline
\end{tabular}

ask God to end the

Covid-19 pandemic so that we will not suffer.
2. I become sad and anxious about news on the death toll because of Covid-19 pandemic; so I offered prayers for them.
$3 . \quad$ I amused myself in order not to get depressed; my daily routine was eat, sleep, watch TV, surf the internet/play online games.
4. I kept myself busy, by cleaning the house and my backyard so that I won't think of Covid- 
19.

5. I stayed at home and I got bored; I asked God why Covid19 pandemic happened.

\section{Economic-Political}

Coping Strategies

1. I made my vacation productive by
cultivating vegetables in my backyard/ I grow different plants and earned some money by selling them.

$$
\text { 2. I released my }
$$
anger by ranting about politicians who are not helping their constituents; and I got pissed off with news about the corruptions of local government officials everywhere.

$$
\text { 3. I joined }
$$
people who went panic buying on alcohol, sanitizers, and groceries that's why supplies and stocks in groceries and

\begin{tabular}{|c|c|c|c|}
\hline $\begin{array}{ll}\text { Social } & \text { Coping } \\
\text { Strategies } & \\
\end{array}$ & & & \\
\hline $\begin{array}{l}1 . \text { I bonded with } \\
\text { my family at home } \\
\text { while we all stayed at } \\
\text { home together. }\end{array}$ & 4.200 & .086 & $\begin{array}{l}\text { Not } \\
\text { Significant }\end{array}$ \\
\hline $\begin{array}{l}2 . \quad \text { I posted my } \\
\text { rants and frustrations } \\
\text { on social media about } \\
\text { what I heard around } \\
\text { me. }\end{array}$ & .118 & .743 & $\begin{array}{l}\text { Not } \\
\text { Significant }\end{array}$ \\
\hline $\begin{array}{l}3 . \quad \text { I get in-touch } \\
\text { with friends/family } \\
\text { members who got } \\
\text { stranded somewhere } \\
\text { else and were not able } \\
\text { to go home to their } \\
\text { families. }\end{array}$ & .458 & .524 & $\begin{array}{l}\text { Not } \\
\text { Significant }\end{array}$ \\
\hline
\end{tabular}
supermarkets run out.

The result of no significant difference in the coping strategies of the respondents across gender revealed that similar program of coping strategies for male and female can be designed as a result of this study. As mentioned in the literature reviews, among the top 5 stress management tactics of the four generations includes Problem-solving, Positive Cognitive Restructuring, Negotiation, Informationseeking, and Emotional Regulation. It means male and female individuals may equally apply strategies depending on their situations and not necessarily on their gender.

\section{Proposed Program to Cope with the Effects of the Covid-19 Pandemic}

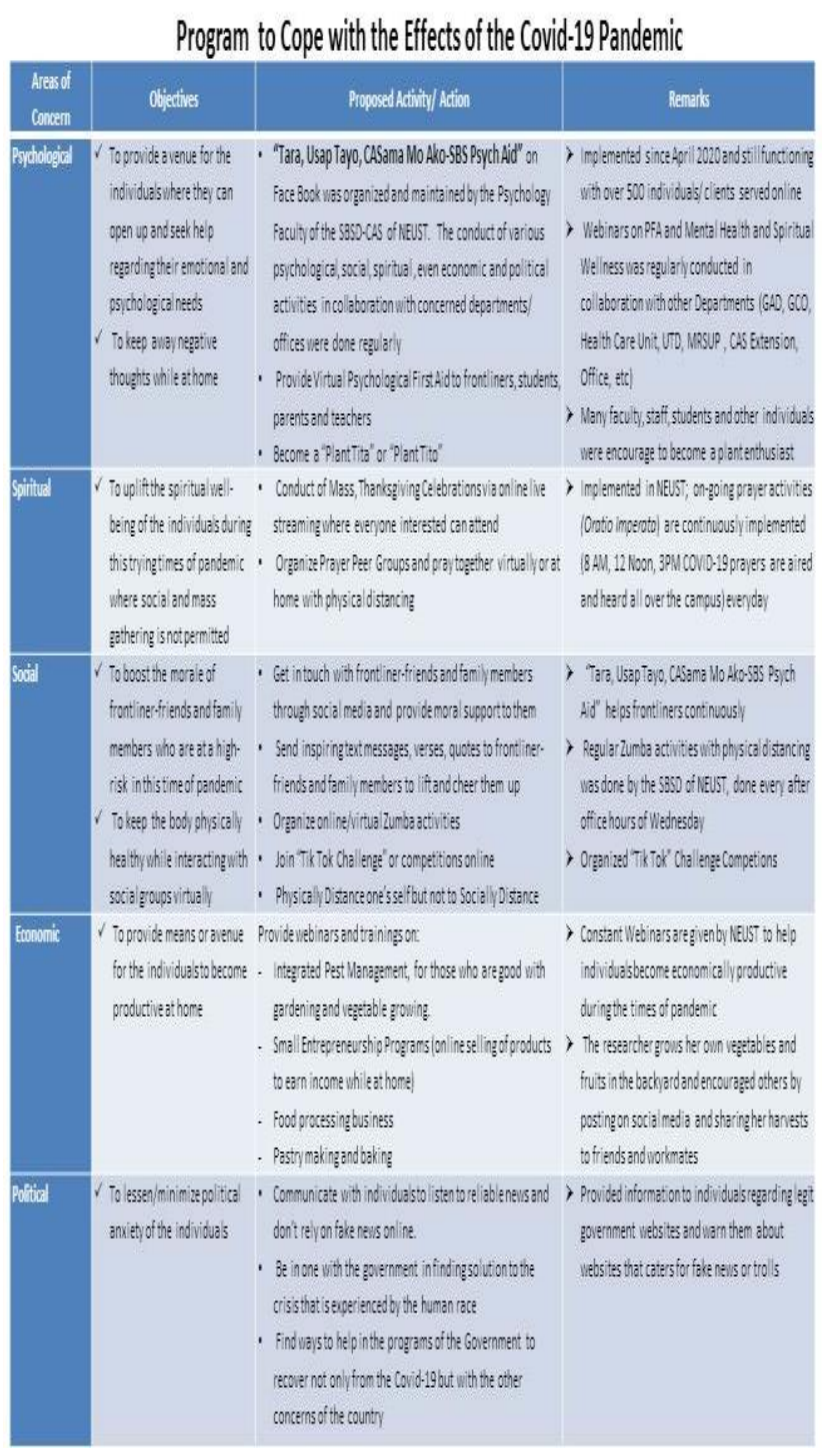

\section{Conclusion}

There are two-hundred individuals who participated in the study; 50 respondents from each generation of Baby Boomers, Generation X, Generation Y and Generation Z; and each generation were divided into 25 females and 25 males. There were 11 coping strategies of the respondents which are composed of five psychological-spiritual; three economic-political; and three social coping strategies. The psychological-spiritual coping strategy of "praying and keeping in mind to ask God to end Covid-19 pandemic so that people will not suffer" was the top most coping strategy of male and female respondents from Baby Boomers and Generation Y; and female respondents from Generation X and Generation Z, but not to the male Gen X and Gen Z. Significant difference was established between one item of psychological-spiritual coping strategies of the respondents and their generation category; while no significant differences were established between the coping strategies of the respondents and their gender. A coping program to 
cope with the effects of the pandemic was designed as an output of this study. Part of coping program was the "Tara, Usap Tayo, CASama Mo Ako-SBS Psych Aid", where various programs in collaboration with different departments and offices of the university are continuously implemented for stakeholders from various sectors, university-wide and nationwide.

\section{Recommendation}

The proposed coping program is recommended for individuals who are experiencing the identified issues and concerns due to the Covid-19 pandemic. The coping program "Tara, Usap Tayo, CASama Mo Ako-SBS Psych Aid", where various activities are continuously implemented for stakeholders from various sectors, university-wide and nationwide should be implemented and replicated by other institutions in order to reach out to as many individuals as possible who needs psychological, social, spiritual and mental health support.

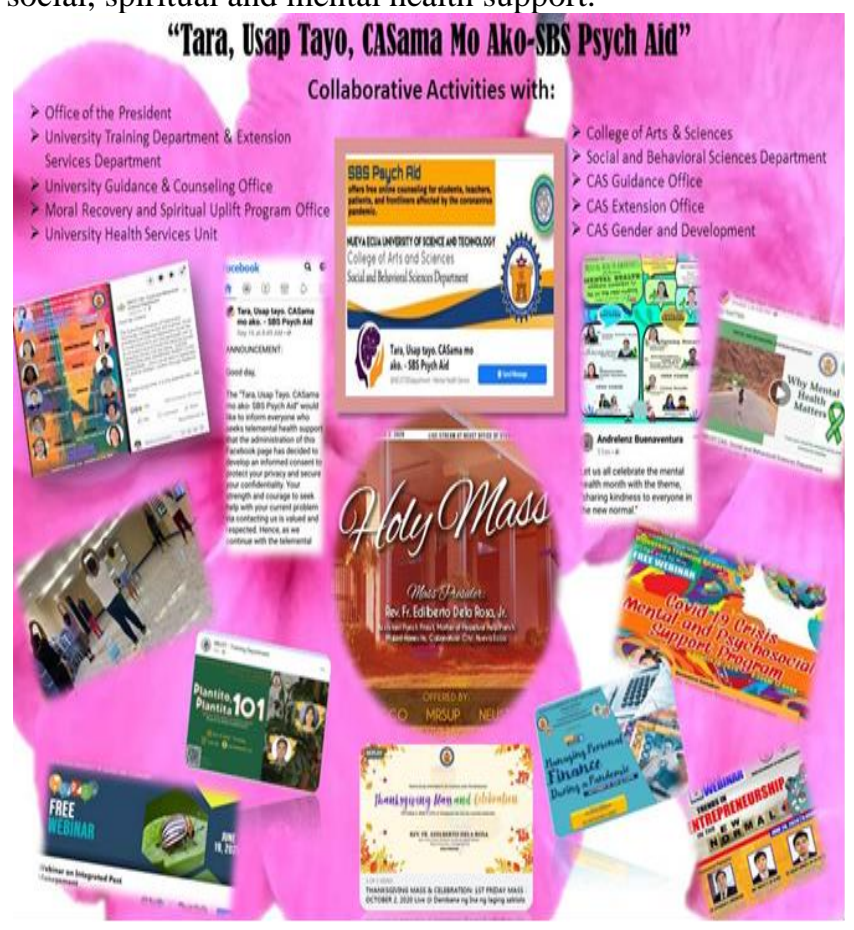

References

[1] Career Planner (2020) Retrieved from:. https://www.google.com/search?sxsrf=AL eKk03Oz9s2yJoAw7p-

TtAXtjzQxZPSMw:1597797325073\&sour ce $=$ univ \& tbm $=$ isch \&q=generation + age + br ackets\&sa $=X \& v e d=2$ ahUKEwjnm_vgqbrAhVoxIsBHe7xAIQQsAR6BAgK EAE\&biw $=1137 \&$ bih $=543 \#$ imgrc $=$ OQf42 PwNRGF4sM. August 15,2020

[2] Endler NS, Parker JDA. Multidimensional assessment of coping: A theoretical analysis. J Pers Soc Psychol. 1990;58:844-854.

[3] Iberdrola (2020). Characteristics Of Generations X, Y And Z. Retrieved from: https://www.iberdrola.com/talent/generatio n-X-y-z August 16, 2020.

[4] Jerabek, Ilona (2017). Coping Through Escapism: New Study Reveals How Today's Youth Deals With Stress. Retrieved from: https://www.prweb.com/releases/2017/11/ prweb14908239.htm\#: :text=Both\%20Ba by $\% 20$ Boomers $\% 20$ and $\% 20$ Generation,se eking\%2C\%20and\%20Emotional\%20Reg ulation). August 12, 2020

[5] Lazarus and Folkman (1984): Stress, Appraisal, and Coping. Retrieved from: https://positivepsychology.com/copingtheory/\#: :text=Lazarus\%20and\%20Folk man\%20(1984)\%2C,coping\%20theory\%2 C\%20defined\%20coping\%20as\%3A\&text $=$ Coping $\% 20$ involves $\% 20$ spending $\% 20 \mathrm{me}$ ntal\%20energy,a\%20problem\%20and $\% 20$ return\%20homeostasis. August 10, 2020

[6] McNamara, Carter (2020). Understand Generational Differences: Guidelines and Resources. Retrieved from: https://managementhelp.org/interpersonal/ understand-generational-differences.htm August 4, 2020

[7] The Strengths and Weaknesses of Every Generation in your Workforce (2020). Retrieved from: https://www.getsmarter.com/blog/careeradvice/know-your-generationals/ (August 17, 2020) 